\title{
Clean Cities
}
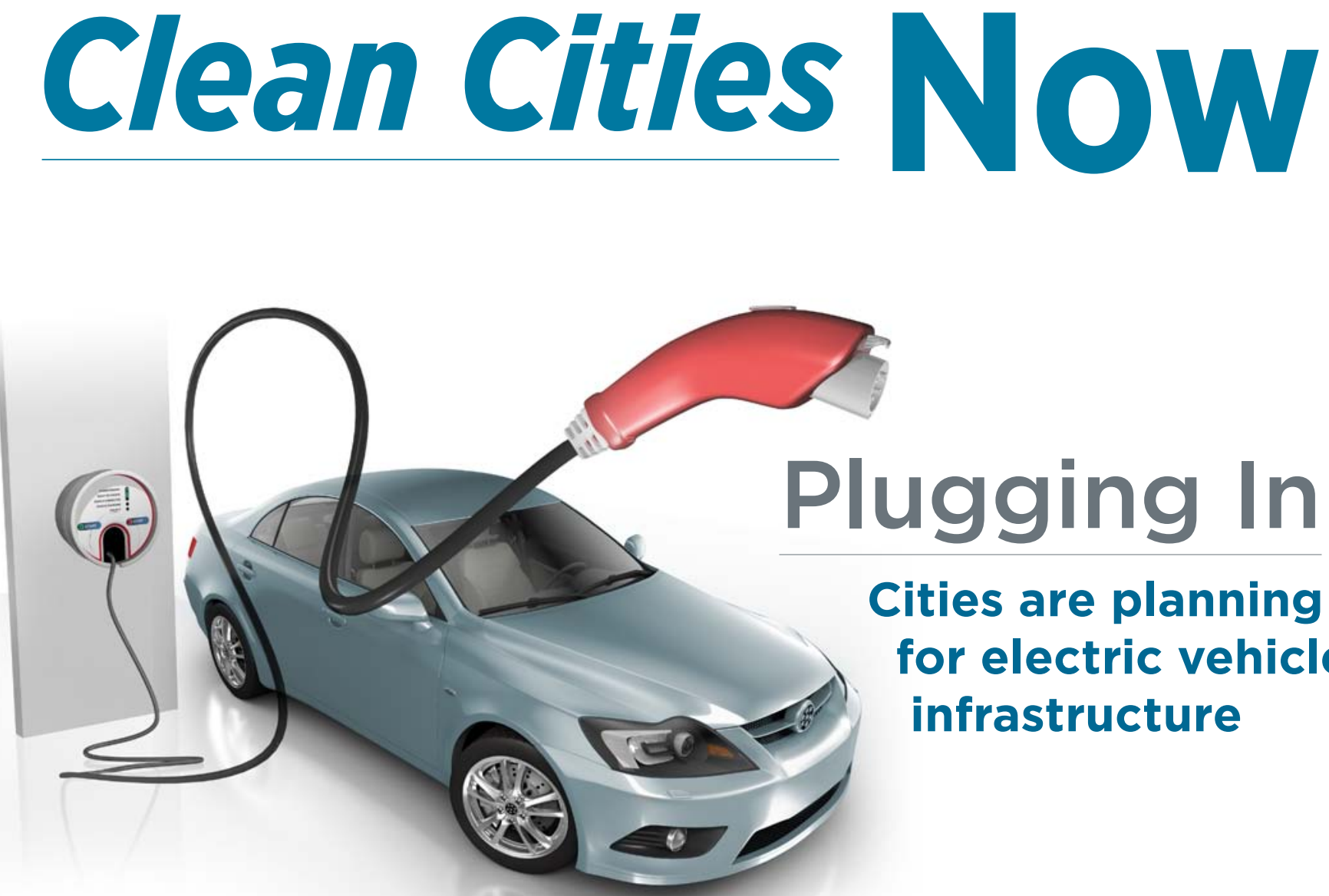

Cities are planning for electric vehicle infrastructure

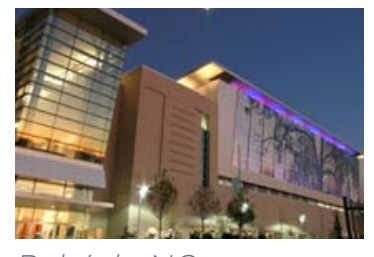

Raleigh, NC

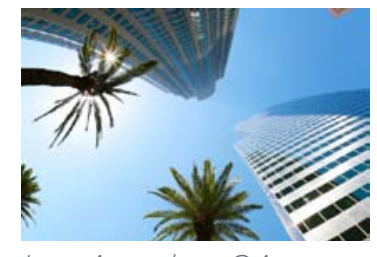

Los Angeles, CA

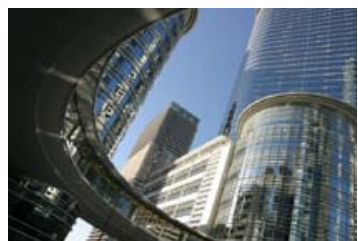

Houston, TX

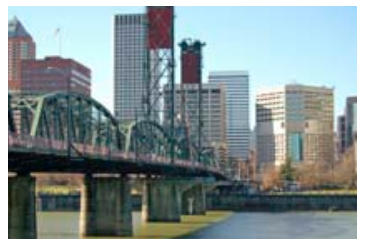

Oregon

Clean Cities TV to Broadcast Coalition Successes

Keeping Trash from Going to Waste with

Renewable Natural Gas

Renewable Fuels in New Jersey

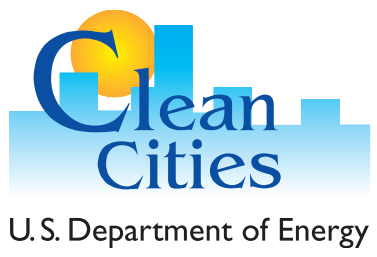




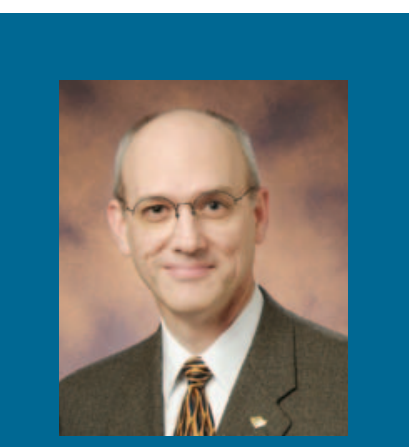

Dennis Smith

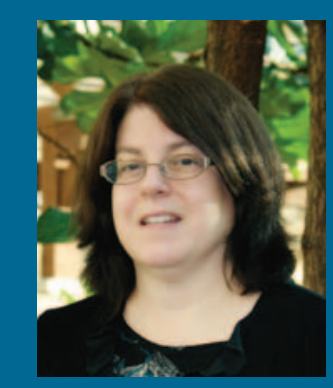

Linda Bluestein

\section{Dear Readers,}

In preparation for the widespread adoption of all-electric and plug-in hybrid electric vehicles, city officials, utility companies, and local leaders are working together to speed up permitting processes for installing home charging equipment. To help cities navigate this new territory, Clean Cities developed case studies detailing the experiences of four electric vehicle pacesetters-the state of Oregon, Houston, Los Angeles, and Raleigh, North Carolina-that are leading the charge. Our feature article on page 6 summarizes the experiences of these areas and includes examples of how electric vehicles are being launched in Clean Cities coalitions across the country.

Renewable natural gas (RNG) is another area we are exploring in this issue. See our Technology Spotlight on page 4 to learn about this gaseous biofuel that's produced from organic waste. The article describes RNG, explains its benefits, and tells how it's being used in the field.

This issue also includes a variety of articles celebrating our coalitions' successful deployment of alternative fuels and advanced vehicles and use of fuel economy and idle reduction measures. Turn to the Coalition News section on page 8 to read about the country's first compressed natural gas ambulance in California, hybrid electric school buses helping kids breathe easier in Kentucky, a million gallons of E85 dispensed in Pennsylvania, and much more.

Also in this issue, you'll find information about the program's new Clean Cities TV online educational channel and new Clean Cities resources available on the Alternative Fuels and Advanced Vehicles Data Center website.

We hope you enjoy this issue. Let us know what you think at cleancities@nrel.gov.
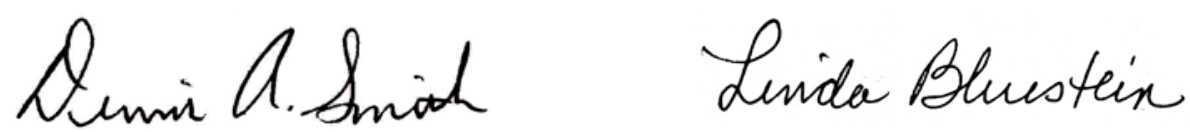

Dennis A. Smith National Clean Cities Director
Linda Bluestein

National Clean Cities Co-Director

U.S. Department of Energy

\section{In This Issue}

Program News .........................

Tool Tips: An Online Tool Directory ..............3

Technology Spotlight: Renewable Natural Gas .....4

Coordinator Profile: Chuck Feinberg, New Jersey

Clean Cities ........................... 5

Feature: Early Plug-In Vehicle Markets Prepare

for Success. .......................6

Coalition News ......................... 8

Ask the Technical Response Service .............11

Resources ................................ 12

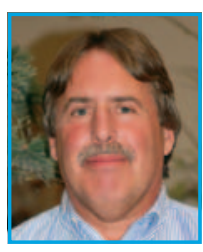

Coordinator Profile: p5

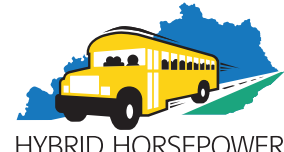

HYBRID HORSEPOWER

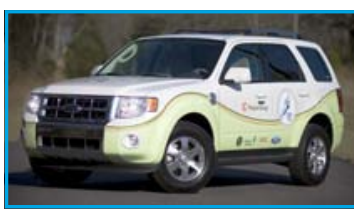

On the Road to

Electrification: p6 p4 FOR KENTUCKY SCHOOLS P10

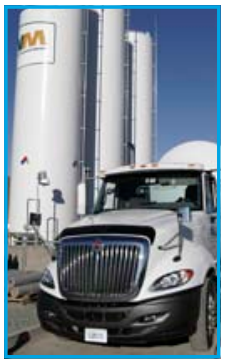

Clearing the Air in Kentucky:

Renewable Natural Gas:

Editor: Heather Proc, National Renewable Energy Laboratory (NREL) Writers: Julie Sutor and Jarett Zuboy, NREL

Design: Dean Armstrong and Joshua Bauer, NREL

Images (from top): from DOE/PIX 17030; by Trish Cozart, NREL/PIX 17004; from Melissa Howell; from Kentucky Clean Fuels Coalition; from Waste Management; from Mike Waters, from Progress Energy Cover images: Car from iStock/15630953. City images, left to right; visitraleigh.com, iStock/3153620, iStock/1681903, iStock/5498746. 
Program News

\section{Clean Cities TV to Broadcast Coalition Successes}

Clean Cities coordinators now have a new outlet to spread the word about alternative fuels and advanced vehicles. Clean Cities TV (CCTV) is an online channel that allows coordinators to showcase successful Clean Cities projects to their peers, stakeholders, the general public, and key audiences like the National League of Cities and the International Association of Fire Chiefs.

"Within the first year, we expect CCTV to have dozens of in-depth videos available at the click of a mouse," says Clean Cities Project Leader Andrew Hudgins, of the National Renewable Energy Laboratory. "CCTV will be a fantastic vehicle for coordinators to reach out to new stakeholders, stay

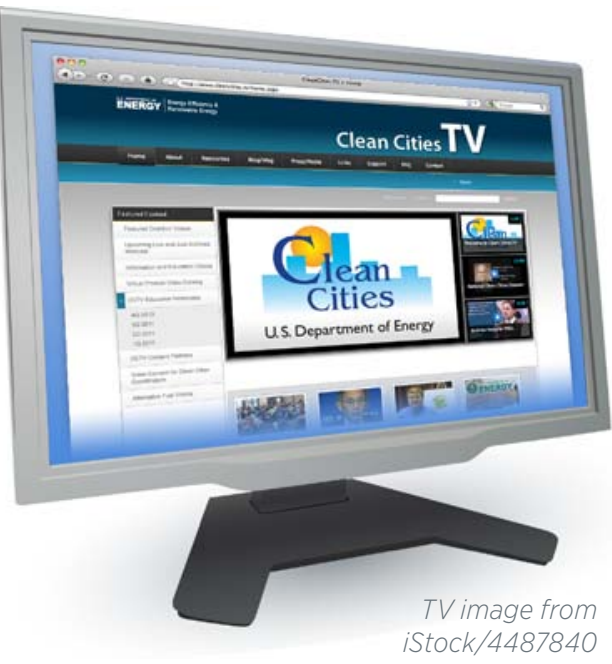

updated on emerging technologies, and give others the opportunity to learn from their progress."

About 40 Clean Cities coordinators and other coalition representatives met in Washington, D.C., in late February for video production training. This pilot group will help create a large portion of CCTV's first season of programming. What's more, the training itself will be available on CCTV as a live and archived webcast, so other interested coordinators can learn to produce videos featuring their own success stories about alternative fuels, idle-reduction technologies, and electric vehicles. And CCTV staff will produce hour-long webcasts and training videos about timely transportation topics.

"CCTV will have an impressive variety of content that's going to amplify the great work coordinators are doing to reduce petroleum consumption. And we'll be adding new programming all the time, so stay tuned," Hudgins says. Visit CCTV at www.cleancities.tv. For more information, contact andrew. hudgins@nrel.gov.

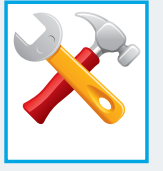

\section{Tool Tips}

Clean Cities develops a wide variety of Web-based tools to help fleets, fuel providers, and consumers find ways to employ alternative fuels, advanced vehicles, and fuel economy improvements.

\section{Clean Cities Tools Page}

The Clean Cities website features a convenient online directory of all its database searches, cost calculators, and interactive maps in one centralized location. The comprehensive tools page helps users quickly navigate to the 25 tools available on the Alternative Fuels and Advanced Vehicles Data Center (AFDC), the premier website for transportation technologies.

Users can find the tools page on the AFDC under Information Resources at www.afdc.energy.gov/tools.

The tools on the AFDC benefit everyone from legislators to fleet owners to consumers. Users can generate a map of the nearest alternative fueling stations, research vehicle specifications for hybrid and alternative fuel light-duty and heavy-duty vehicles, compare mileage estimates, calculate cost savings for natural gas or flexible fuel vehicles, search for incentives and rebates, and more.
"We are always striving to make the vast amount of information on the AFDC as accessible as possible," says Johanna Levene, NREL technology supervisor for the AFDC.

"By putting links to all of our tools and searches on one Web page, we are helping users find what they need fast and introducing them to some useful tools and searches they might not even know existed."

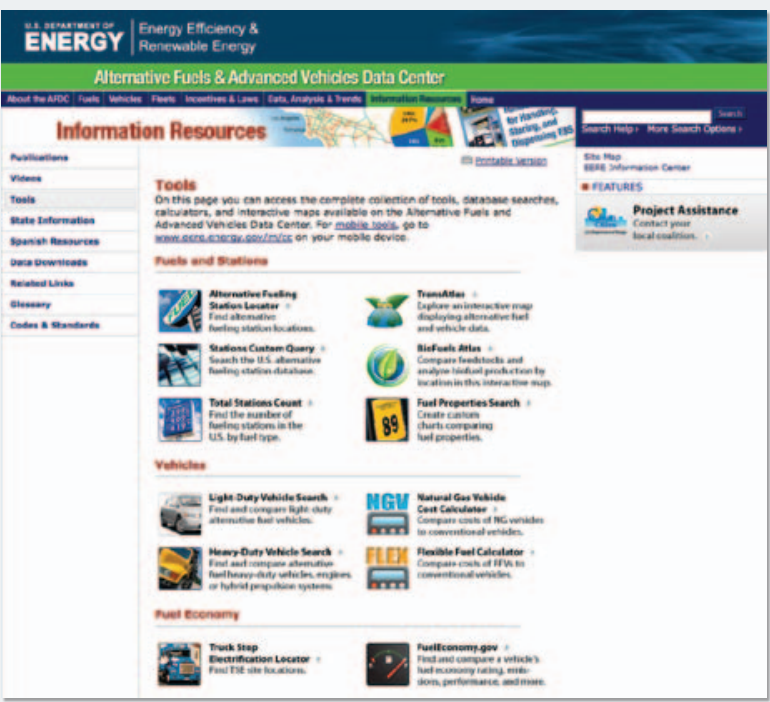




\section{Technology Spotlight}

\section{Renewable Natural Gas}

\section{A Gaseous Biofuel that Keeps Trash from Going to Waste}

When you think of biofuels, you probably think of ethanol and biodiesel. Renewable natural gas ( $\mathrm{RNG}$ ) might not be the first thing to cross your mind, but this gaseous biofuel offers powerful benefits and springs from one of the world's most ubiquitous resources-organic waste.

When organic wastes decompose without oxygen - a process called anaerobic digestion - they typically produce a gaseous mixture of about $35 \%$ to $55 \%$ methane, $20 \%$ to $45 \%$ carbon dioxide, other gases, and trace contaminants. This impure mixture is called biogas. Purifying biogas results in a fuel called RNG or biomethane, with a methane content greater than $90 \%$.

Biogas comes from various organic wastes, including sewage, municipal solid waste, agricultural and industrial waste, and animal manure. Today, landfills are the largest source of captured biogas in the United States. In 1996, the Landfill Rule of the Clean Air Act required large landfills to collect and "destroy" their biogas by flaring it. This converts methane (a potent green-

\section{Gas Terminology}

- Biogas, produced by the anaerobic digestion of organic waste, is a relatively impure mixture of methane, carbon dioxide, other gases, and contaminants. With minimal processing, biogas can be used for electricity generation and some industrial applications.

- Renewable natural gas (RNG) is made by purifying biogas to a high methane content. RNG can be used in natural gas vehicles and distributed via natural gas pipelines (biogas is generally too impure for these applications). RNG is also called biomethane.

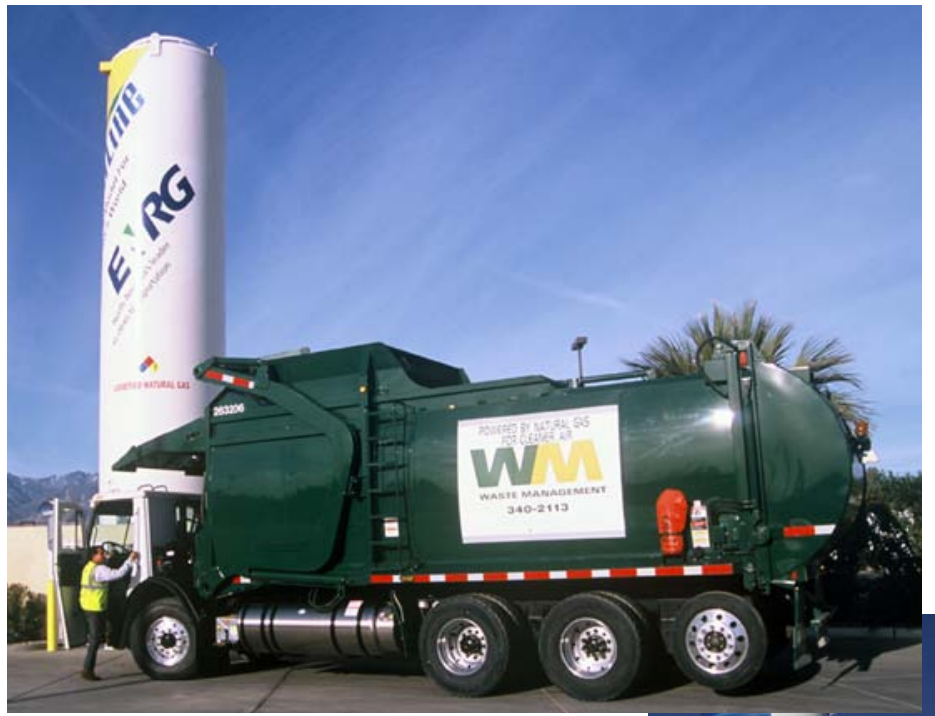

Most of the vehicles that use RNG in the U.S. are refuse trucks. At California's Altamont Landfill, tankers fill up with liquefied RNG and distribute it for use in 350 refuse trucks throughout the state. Photos from Waste Management

house gas) and harmful organic gases into less-harmful compounds such as carbon dioxide.

Instead of merely flaring biogas, some landfills began capturing and using it. The U.S. Environmental Protection Agency (EPA) established the Landfill Methane Outreach Program (LMOP) to encourage this practice. Today, 541 landfills are producing electricity equivalent to about $0.6 \%$ of U.S. electricity consumption, and natural gas equivalent to about $0.5 \%$ of U.S. natural gas consumption. The EPA estimates that biogas from another 510 U.S. landfills could be harnessed for energy production.

Biogas requires relatively little processing for use in electricity production and some industrial applications. Most U.S. landfill energy projects generate electricity onsite. A few projects purify the biogas and inject the resulting RNG into natural gas distribution pipelines or use it as a vehicle fuel. The biogas must be processed and compressed for these applications, which increases costs. On the other hand, the products can be of higher value than electricity or displace fuels that produce more harmful emissions.

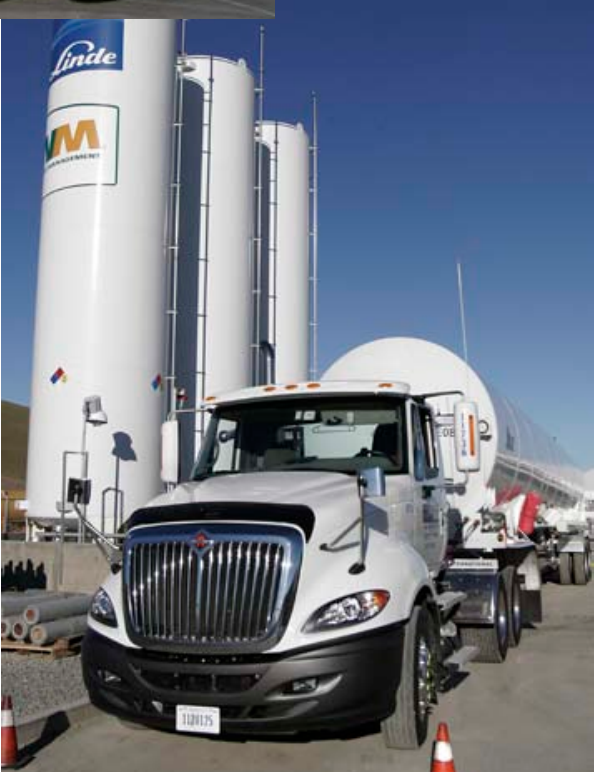

"Landfill energy projects take advantage of the opportunities that are available," says Marianne Mintz, principal investigator for Clean Cities' RNG analysis at Argonne National Laboratory (ANL). Electricity is usually a good option if a grid connection is available. Gas distribution can work if the source is close to a gas pipeline or a facility that needs process heat. For transportation, fueling infrastructure and natural gas vehicles are required.

Because RNG can cost more than conventional natural gas, incentives 
are also important. Funding from public or private organizations can make the difference between a project being financially viable or not. On the policy side, biogas-electricity projects can help utilities satisfy state renewable portfolio standards. RNG transportation projects can help satisfy state low-carbon fuel standards and the federal Renewable Fuel Standard.

Today, only a handful of U.S. landfills, dairy farms, and wastewater treatment plants produce RNG for transportation, and fewer than 500 natural gas vehicles currently use it. In contrast, Sweden, which has the world's most aggressive RNG program, fuels thousands of natural gas vehicles with RNG. Clean Cities is working to expand RNG use in transportation. Projects in Georgia and Washington received funding through Clean Cities as part of the American Recovery and Reinvestment Act of 2009. Clean Cities has also supported RNG research and development. "RNG projects are usually large and take time to put together, so support and patience are important," says Mintz.

Using RNG as a vehicle fuel provides important benefits. A recent ANL study found that landfill-derived RNG can reduce vehicular fossil fuel consumption and greenhouse gas emissions by more than $70 \%$ compared with petroleum gasoline and diesel and conventional natural gas.

The potential supply of RNG has not been well established. However, it is clear that the United States-with many untapped sources of organic waste-has just scratched the surface of this renewable resource.

For more information, visit the EPA's LMOP (www.epa.gov//mop) and AgStar Program (www.epa.gov/agstar) and the Clean Cities Waste-to-Wheels workshop (www.eere.energy.gov/cleancities) waste_to_wheels.htm/).

Each Technology Spotlight details an alternative fuel or technology and companies that offer or use it. Clean Cities does not endorse the technologies or companies featured.

\section{Coordinator Profile}

\section{Chuck Feinberg Builds Momentum for Alternative Fuels in New Jersey}

\author{
"You're from New Jersey? What exit?" That old joke \\ annoys some New Jersey residents, but it suggests \\ how central vehicles and highways are to life in \\ the Garden State. For New Jersey Clean Cities Coalition (NJCCC) Coordinator Chuck \\ Feinberg, that very car culture makes New Jersey the perfect proving ground for \\ alternative fuels and advanced vehicles.
}

Feinberg first became involved with NJCCC in 2009 as an environmental consultant, having worked on everything from Superfund cleanups to renewable energy to biofuels development. "I took a real interest in the biofuels side of things and learned that there really are viable alternatives to petroleum," Feinberg says. "I became aware of Clean Cities, saw its potential, and got involved. One thing led to another, and now I'm the coordinator."

Shortly after Feinberg took the coalition's helm, he rounded up several stakeholders to develop a proposal for a statewide natural gas vehicle and infrastructure project. Feinberg applied for funding through the American Recovery and Reinvestment Act, and Clean Cities awarded NJCCC $\$ 15$ million to deploy almost 300 natural gas garbage trucks and shuttle buses and six new fast-fill compressed natural gas (CNG) fueling stations throughout Atlantic and Morris Counties and the cities of Newark, Camden, and Trenton. The project established New Jersey's first and only statewide network of alternative fuel infrastructure and is projected to displace at least 1.8 million gallons of petroleum each year.

Since the project's inception, Feinberg's phone has been ringing off the hook with inquiries from public and private fleets interested in incorporating natural gas into their own operations. "We've become a well-known entity in New Jersey. We've been able to establish ourselves as the go-to organization in the state on alternative fuel technologies and funding opportunities," he says.

Natural gas isn't the only thing on NJCCC's agenda under Feinberg's leadership: The coalition is also busy laying the groundwork for electric vehicle (EV) deployment. NJCCC has a contract with the New Jersey Department of Environmental Protection to advise the state on policy issues regarding EVs. Under the contract, NJCCC wrote a report recommending a package of measures that would encourage the EV market. Feinberg also serves as the facilitator for a statewide interagency task force for EVs.

Feinberg recently helped form a renewable natural gas working group that includes 20 representatives from industry and academia. The group is working to find ways to develop renewable natural gas, or biomethane, as a transportation fuel in New Jersey, since most existing state incentives apply to the fuel's use in electricity generation.

Feinberg's tireless efforts and impressive progress have not gone unnoticed. He was one of eight nominees for the 2010 Clean Cities Coordinator of the Year Award. And he shows no signs of slowing as he looks to the future.

"For the people who live here and those who are just passing through, we need to make sure that New Jersey has the infrastructure to make petroleum the fuel of the past," Feinberg says. 


\title{
Feature
}

\section{Early Plug-In Vehicle Markets Prepare for Success}

\author{
Oregon, Houston, Los Angeles, and Raleigh are on the road to electrification
}

The first Chevrolet Volt and Nissan Leaf plug-in electric vehicles (PEVs) were delivered to U.S. customers last December, accompanied by high hopes for a petroleum-free transportation revolution. However, this revolution will require preparation and the coordinated efforts of many stakeholders. Oregon; Houston; Los Angeles; and Raleigh, North Carolina, are among the nation's PEV leaders. Their preparations and deployment activities are summarized below and detailed on the Alternative Fuels and Advanced Vehicles Data Center website at www.afdc.energy.gov/plugin case_studies.

\section{Oregon}

To meet its ambitious greenhouse gas (GHG) reduction goals, Oregon must slash vehicular GHG emissions. The state identified PEVs as a way to achieve this goal, because they draw on the state's clean electricity: More than half comes from hydropower, and a renewable portfolio standard is requiring utilities to add even more clean electricity sources.

Oregon's PEV preparations have led to pro-PEV legislation and partnerships among more than 60 state agencies, local governments, utilities, and private organizations. A Public Utility Commission docket is investigating the role of utilities in PEV deployment. Oregon is participating in the EV Project, which will deploy more than 2,000 residential and public charging stations in the state during 2010 and 2011. Oregon also received support for fast-charging stations from the U.S. Department of Transportation's TIGER II grant program and the American Recovery and Reinvestment Act (ARRA) via the U.S. Department of Energy's (DOE) State Energy Program.

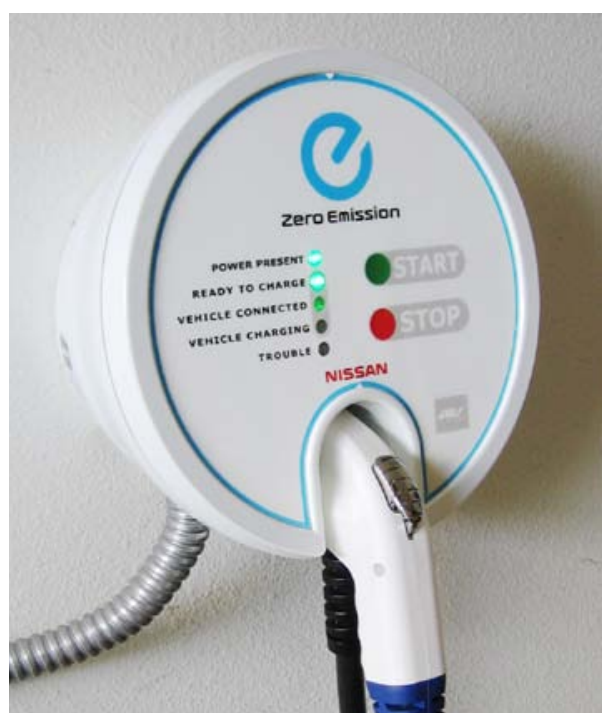

The first wave of PEVs began arriving in Oregon in late 2010. "Oregon worked hard to prepare for PEVs," says Rick Wallace, senior policy analyst at the Oregon Department of Energy and coordinator of the Columbia-Willamette Clean Cities Coalition. "Now, we're tracking the arrival of the vehicles, and the team we've built will respond to issues that arise to ensure a successful deployment."

\section{Houston}

Houston is an energy and transportation giant, with the nation's largest petrochemical and refining complex, and onroad travel exceeding 140 million vehicle miles per day. Spurred by concerns about air quality and GHG emissions, Houston is preparing to become a PEV giant as well. "We are a car culture in the middle of an oil and gas town," says Laura Spanjian, director of Houston's Office of Sustainability. "Promoting PEVs is a more efficient way to reduce emissions than only trying to get people out of their cars."

Houston brought together numerous public and private partners to establish
This residential charging station is used by Oregon's first Nissan Leaf owner, who describes his new PEV as a "computer on wheels" because he manages the battery charging via his laptop computer. Photo from Rick Wallace, Oregon Department of Energy

the Houston Electric Vehicle Initiative. It also received PEV grants from the U.S. Environmental Protection Agency's Climate Showcase Communities Program and from DOE via the Texas State Energy Conservation Office. Many of Houston's PEV buyers will receive a free residential charging station as part of the Electric Vehicle Initiative, while the City of Houston and energy provider NRG EV Services are installing more than 200 municipal and public stations. An ongoing project will help determine if transformers in neighborhoods with many PEV charging stations have adequate capacity. Houston is also participating in the EV Project and Project Get Ready. Texas' first PEV arrived in Houston in January. The City of Houston fleet will begin receiving PEVs in March.

\section{Los Angeles}

Populous Los Angeles, with one of the nation's highest per-capita car-ownership rates, helped lead the deployment of PEVs in the 1990s and is committed to deploying today's PEVs. The Los Angeles Department of Water and Power (LADWP), a municipal utility, serves the city's electric needs. Permitting in the utility's service area is performed entirely by the city's Department of Building and Safety. Both of these factors facilitate PEV and charging-station deployment.

LADWP is upgrading and adding public charging stations, using discounted electric rates to promote off-peak PEV 
charging, and subsidizing residential charging stations for customers who agree to have their charging data collected. Los Angeles is also negotiating installation of residential and public charging stations as part of ChargePoint America and the EV Project. Charging-equipment provider EV Connect and the Los Angeles County Metropolitan Transportation Authority are collaborating to analyze the integration of PEVs and charging infrastructure with a public transit network.

LADWP also initiated the Southern California Regional Plug-In Electric Vehicle Plan to foster collaboration among stakeholders and establish regional PEV charging infrastructure.

"We want to bring in the region's other cities, utilities, and businesses so our efforts have a larger impact," says LADWP Environmental Specialist Adrene Briones.

\section{Raleigh}

Fast-growing, high-tech Raleigh — and the surrounding Research Triangle Region - became PEV leaders by joining Project Get Ready in 2009. One of the first steps was assembling a diverse

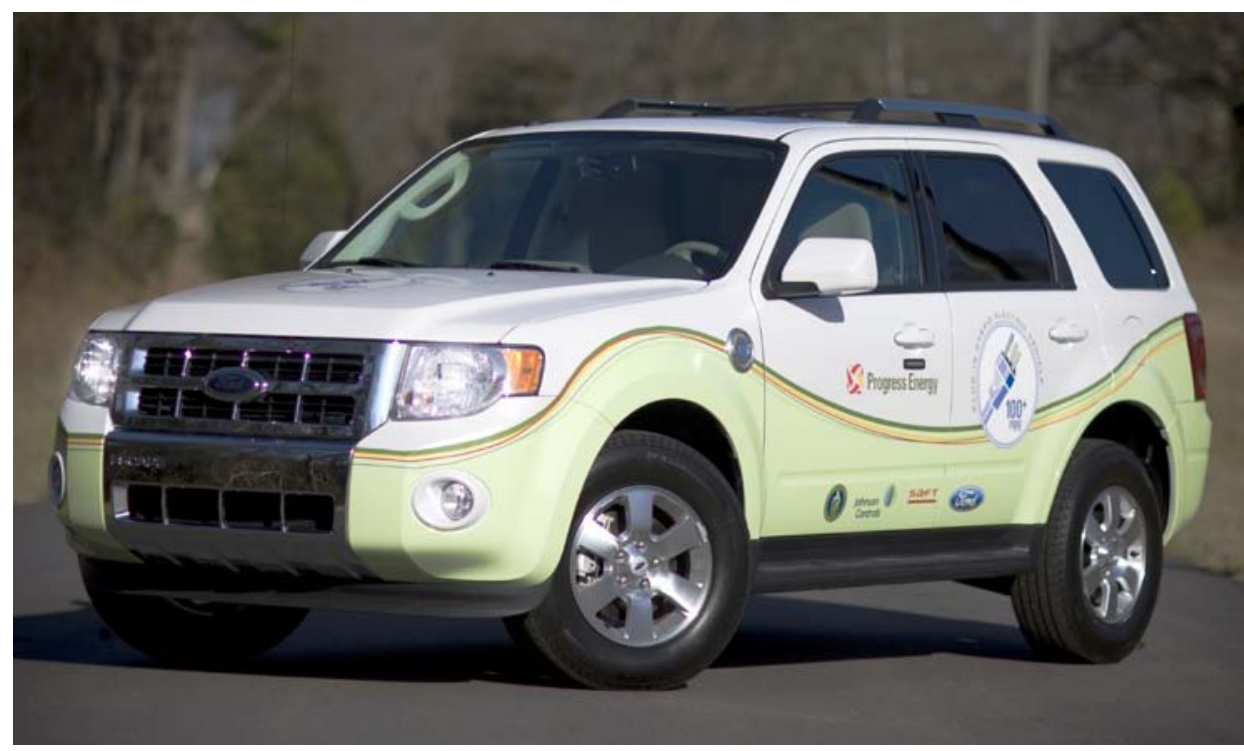

A Ford Escape PEV operated by Progress Energy, Raleigh's utility. Photo from Mike Waters, Progress Energy/PIX 18527

team of stakeholders to overcome barriers to PEV deployment, educate consumers about PEVs, establish charging infrastructure, and explore PEV-related economic-development opportunities. "It's about helping all members of a community understand, plan for, and implement electrified transportation initiatives," says Jeff Barghout, Director of Transportation Initiatives for Advanced Energy, a
Raleigh-based nonprofit that is coordinating North Carolina's Project Get Ready effort.

The Triangle Clean Cities Coalition is actively involved as well, helping develop a PEV-readiness roadmap, providing technical support to corporate and government partners, and making PEV information available to targeted stakeholders and the public.

\section{Residential Charging Station Permitting and Inspection Processes}

The installation of Level 2 (240V) residential charging stations is vital to widespread PEV deployment. To facilitate standard residential installations, Oregon, Houston, Los Angeles, and Raleigh have developed streamlined permitting and inspection processes. This table contains key facets of each area's approach.

\begin{tabular}{|c|c|c|c|c|}
\hline & Oregon & Houston & Los Angeles & Raleigh \\
\hline Permitting & $\begin{array}{l}\text { A licensed electrician } \\
\text { buys } 10 \text { Oregon “Minor } \\
\text { Installation Labels" online } \\
\text { for } \$ 140 \text {. Each label can } \\
\text { be used to permit one } \\
\text { standard installation. }\end{array}$ & $\begin{array}{l}\text { A licensed electrician ap- } \\
\text { plies for a permit online } \\
\text { for } \$ 35 \text {. Approval is auto- } \\
\text { matic and instantaneous } \\
\text { for standard installations. }\end{array}$ & $\begin{array}{l}\text { A licensed electrician ap- } \\
\text { plies for a permit online } \\
\text { for } \$ 75 \text {. Approval is auto- } \\
\text { matic and instantaneous } \\
\text { for standard installations. }\end{array}$ & $\begin{array}{l}\text { A licensed electrician or } \\
\text { the charging station cus- } \\
\text { tomer obtains a permit by } \\
\text { visiting a city inspection } \\
\text { center, requiring about } \\
\text { one hour and a } \$ 74 \text { fee. }\end{array}$ \\
\hline Inspection & $\begin{array}{l}\text { The electrician logs each } \\
\text { completed installation, } \\
\text { and one in } 10 \text { of the } \\
\text { electrician's installations } \\
\text { is inspected by the local } \\
\text { jurisdiction. }\end{array}$ & $\begin{array}{l}\text { The electrician requests } \\
\text { an inspection from the } \\
\text { Code Enforcement Group. } \\
\text { Inspections are completed } \\
\text { the same day for requests } \\
\text { received before noon. } \\
\text { and within } 24 \text { hours for } \\
\text { requests after noon. }\end{array}$ & $\begin{array}{l}\text { The electrician requests } \\
\text { an inspection from the } \\
\text { Department of Building } \\
\text { and Safety, which is com- } \\
\text { pleted within } 24 \text { hours of } \\
\text { the request. }\end{array}$ & $\begin{array}{l}\text { The electrician or } \\
\text { customer schedules an } \\
\text { inspection. If the city } \\
\text { receives a call by } 4 \text { p.m., } \\
\text { the inspection is per- } \\
\text { formed the next day. }\end{array}$ \\
\hline
\end{tabular}




\section{Coalition News}

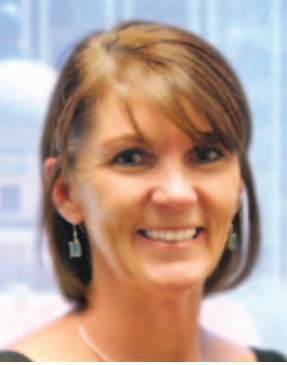

\section{South Central Region}

Colleen

Crowninshield

Tucson

Clean Cities

\section{Tucson Well on Its Way to Go Electric}

Plug-in electric vehicles (PEVs) from major auto manufacturers are just now hitting the market, and southern Arizona is welcoming them with open arms.

A determined and enthusiastic group of Tucson Clean Cities (TCC) stake- holders spent the past year laying the groundwork for the deployment of PEVs. The work kicked off in 2009 with a PEV infrastructure workshop. The event's 150 attendees included representatives from Tucson Electric Power (the local utility company), PEV manufacturers, charging equipment manufacturers and installers, government planning departments, and other stakeholders. The overarching goal of the workshop was to develop a plan that would thoroughly prepare the Tucson area for the arrival of PEVs.

Those early preparations caught the eye of PEV charging equipment developer ECOtality, and in March 2009, TCC signed agreements with Nissan and ECOtality, making Tucson one of the official launch markets for the Nissan Leaf. Shortly thereafter, Ford selected Tucson as a launch city for its all-electric Focus.

Since the kick-off workshop, a growing number of partners and stakeholders has been waging a nonstop, twopronged campaign of education and infrastructure planning. TCC hopes the effort will result in the deployment of 500 PEVs, 250 Level 2 charging stations, and five DC fast chargers within the next two years. So far, all 255 stations have been plotted, and six are already installed. Pima County govern-

continued on p9 >

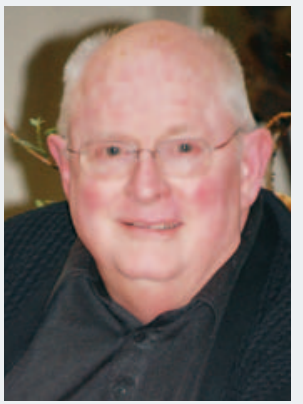

\section{Western Region}

Richard Cromwell III, Coachella Valley Region Clean Cities

\section{Natural Gas to the Rescue}

The City of Palm Desert, California, is a long-time proponent of natural gas as a transportation fuel. In 2010, the municipality took this clean-burning alternative fuel to new heights when it unveiled the country's first natural gas ambulance.

Palm Desert and a number of its neighboring communities in the Clean Cities Coachella Valley Region (CCCVR) coalition have been using compressed natural gas (CNG) to power municipal fleets and the regional transit agency for more than a decade. So when Palm Desert needed a new ambulance, searching for a CNG option made perfect sense. However, research by CCCVR revealed that U.S. original equipment manufacturers don't produce CNG ambulances. Undeterred, representatives from CCCVR, Palm Desert, and Riverside County Fire Department were determined to turn the problem into an opportunity by launching a pilot project that would develop and showcase the use of clean fuel in the world of emergency medical services (EMS).

Palm Desert purchased an ambulance patient compartment and a Ford E450 gasoline chassis from Houstonbased Frazer Bilt. The city then contracted with BAF, a natural gas vehicle provider owned by Clean Energy, to convert the ambulance to run on CNG. Frazer Bilt worked closely with BAF and Riverside Fire representatives to customize the patient compartment in a way that would accommodate the natural gas engine without compromising any EMS functionality. The vehicle hit the road in January 2010, taking advantage of the Coachella Valley's existing CNG fueling infrastructure (all three of the region's hospitals have a CNG station within a reasonable distance).

For the past year, the fire department has been working diligently to keep careful records and determine the best dispatch and fueling protocols for the new ambulance. City officials have closely monitored the project, staying up to date on progress, glitches, and solutions at every step of the way. Thus far, feedback from drivers, EMS personnel, and even patients has been extremely positive, with many commenting on the welcome absence of exhaust fumes. According to the City of Palm Desert, the new ambulance's particulate emissions are $95 \%$ lower than those of a comparable diesel vehicle, and it reduces diesel fuel use by about 1,500 gallons annually. CCCVR and the City of Palm Desert are encouraged by the success of the pilot project and hope it will be replicated in other communities. 
ment, the Town of Oro Valley, and the University of Arizona are leading the pack, each with a strong commitment to PEV success.

Outreach to the general public and major employers is a cornerstone of TCC's efforts to take transportation electric in Tucson. A steady stream of great media coverage is creating a palpable buzz throughout the area, and TCC takes every opportunity to make presentations to the chamber of commerce, Rotary Clubs, and other community groups. The coalition conducts two or three outreach events each month, appears on the "Mrs. Green Goes Mainstream" radio show every other week, offers community workshops, writes op-ed pieces for area newspapers, and organizes press events around all PEV deployment developments, such as the installation of new charging equipment.

Unwavering support from Tucson Electric Power has been key to the impressive momentum behind the deployment of PEV infrastructure. The utility works hand in hand with TCC on everything from broadcasting the alternative fuels message to working out nitty gritty technical details and educating elected officials and community planners.

Looking ahead, TCC hopes to expand its PEV work beyond Tucson to the major transportation corridors that lead to Phoenix and San Diego. And the coalition is also eager to share its experiences with other Clean Cities coalitions seeking to deploy PEVs in their own communities.

\section{Share Your News}

Each issue of Clean Cities Now features Coalition News articles from coordinators representing each region. If you're interested in writing an article, contact heather.proc@nrel.gov with your story idea. If we choose your idea, we'll contact you for an interview.

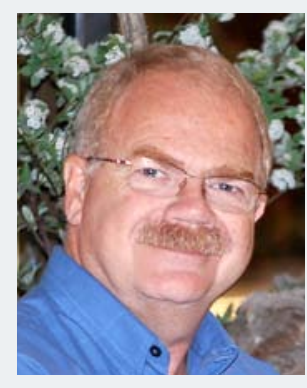

\section{Northeast Region}

Steve Russell, Massachusetts Clean Cities

\section{Staples and Massachusetts Clean Cities Deliver on Fuel Efficiency}

Many people know that Staples is a serious competitor in the office-product supply industry. What they may not know is that the company is also a Massachusettes Clean Cities stakeholder leading the way in reducing petroleum consumption.

With $\$ 24$ billion in sales in 2009 and a fleet of 2,200 vehicles in the U.S. and Canada, the movement of products is a big part of Staples' operations. And through its Staples Soul corporate accountability initiative, the company has made a commitment to transporting its goods sustainably.

In 2006, Staples North American Fleet Equipment Manager Michael Payette began installing electronic speed control modules in Staples' medium-duty diesel delivery trucks. At a cost of only $\$ 7$ per truck, the modules prevent the vehicles from traveling faster than $60 \mathrm{mph}$, improving their fuel economy from the industry standard $8.1 \mathrm{mpg}$ to $10.1 \mathrm{mpg}$. Speed control, in combination with electronic idle reduction and driver training programs, has improved overall fuel economy in Staples' delivery fleet by $30 \%$.

Today, all of Staples' trucks are equipped with speed control modules, and the company has saved a cumulative 2.9 million gallons of fuel and prevented the emissions of 32,000 tons of carbon dioxide. Staples' annual conventional fuel savings are approaching 1 million gallons.

At the project's start, some drivers worried the speed controls might get in the way of timely deliveries. But analysis by Staples found that driving time increased by only seven minutes per day. Furthermore, the extra time on the road was offset by less frequent trips to the fuel pump. And research by Staples' risk management department found no safety issues associated with limiting truck speed.

Staples is now working to further improve the fuel efficiency of its fleet by incorporating all-electric trucks in high-density urban delivery areas, diesel-electric hybrids in urban delivery areas, lighter composite materials in vehicle body construction, and dynamic routing software. Introduction of 53 all-electric trucks, manufactured by Smith Electric Vehicles, began in November 2010.

"Over time, we'll look to increase the number of these trucks in the Staples fleet as an effective way to service our delivery customers while reducing our carbon emissions," Payette says. 


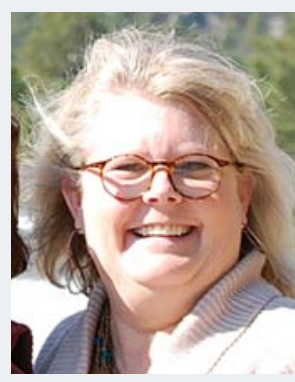

\section{Southeast Region}

Melissa Howell, Commonwealth Clean Cities Partnership

\section{Hybrid Horsepower for Kentucky Schools}

New hybrid electric school buses are clearing the air in Kentucky with help from the Commonwealth Clean Cities Partnership (CCCP). Thirty-one public school districts across the state have ordered 101 ThomasBuilt and Interna-

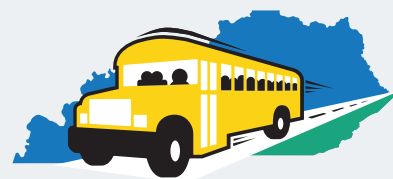

HYBRID HORSEPOWER FOR KENTUCKY SCHOOLS

Image from Kentucky Clean Fuels Coalition

tional hybrid electric school buses, thanks to funding from the American Recovery and Reinvestment Act.

The new bus purchases are part of a project to introduce 213 hybrid school buses throughout the state. In August 2009 , the U.S. Department of Energy awarded $\$ 13$ million to the Kentucky Department of Education to cover the incremental costs of hybrid buses over traditional diesel buses. Once the project is complete, Kentucky will have the largest hybrid electric school bus fleet in the nation, translating to significant reductions in petroleum consumption. Manufacturers estimate fuel savings will be as high as $40 \%$, with increases in fuel mileage from 7.5 to 12 miles per gallon, relative to standard diesel buses.

Kentucky's hybrid school bus project will serve as an example for school systems across the country. The Kentucky Clean Fuels Coalition (KCFC), which houses the state's Clean Cities program, will gather performance data to share with other states, as well as with Kentucky students, who will be active participants in the project. KCFC plans to engage the students with onsite energy teams that can use the information for science and math classes.

"The hybrid school bus project not only serves as a means to improve efficiency and be environmentally conscious," Kentucky Education Commissioner Terry Holliday says. "This project will also provide students with learning opportunities across many subject areas. Teachers can develop lesson plans related to fuel consumption, air quality, and transportation costs, bringing real-world knowledge and hands-on experiences into the classroom."

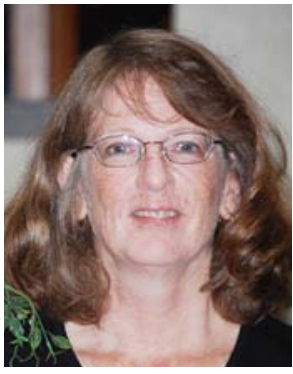

\section{Northwest Region}

Beth Baird

Treasure Valley Clean Cities

\section{Small Idaho County Goes Big in Petroleum Reduction}

With a population of about 200,000 , Canyon County, Idaho, may not be very big. But its recent successes in reducing petroleum use are enormous.

About two years ago, Canyon County Fleet Manager Mark Tolman puzzled over a problem shared by countless public officials throughout the country: How would he provide a high level of service to his community in the face of shrinking budgets?

Tolman worked with Treasure Valley Clean Cities to develop a strategy that made better use of his existing fleet resources while also embracing new technologies and fuels.He convened a "utilization team" that sought the input of vehicle drivers in every county department. He also purchased fleetmanagement software that allowed him to better track and scrutinize fuel use, vehicle utilization, idling time, and employee mileage reimbursements.

Armed with the new data, Tolman trimmed the county's fleet from 325 vehicles to its present 220 . He developed a new replacement schedule that incorporated E85 and hybrid vehicles into the fleet wherever possible. He started filling tires with nitrogen. And the Fleet Department installed two new 12,000-gallon fuel tanks (one for gasoline, one for ethanol) and a blending dispenser that allows workers to specify the level of ethanol in the fuel they use.

Before Tolman's project began, he knew fuel was being wasted in idling patrol cars in the Sheriff's Department, but once he had the hard numbers in front of him, "It was just shocking," he says. Each patrol car was idling for up to five hours per day, using about one gallon of fuel per hour of idle time.

Over the past year and a half, Canyon County fleet workers installed idle- reduction equipment on nearly all of the 65 patrol cars in the sheriff's department, eliminating 36 "ghost miles" and 100 pounds of carbon dioxide emissions per day for each car. "We're cutting our fuel use, and we're doing it safely - everything runs at peak performance. We're never going to leave our people hanging or compromise their safety," Tolman says.

Today, the Canyon County Fleet Department is eliminating an estimated 1.4 million pounds of carbon dioxide emissions every year and improving its vehicles' fuel economy by $4 \mathrm{mpg}$ to $6 \mathrm{mpg}$. According to Tolman, the E85 station has already paid for itself.

"Using technologies that are already widely available, we realized immediate cost savings to Canyon County," he says. "We are maintaining a top-notch fleet, trimming our budget with minimal disruptions to ongoing operations, reducing our dependence on foreign oil, shrinking our environmental footprint, and serving as an example for other fleets." 


\section{Wis Mid-Atlantic and Great Lakes Region}

Tony Bandiero

Greater

Philadelphia

Clean Cities

\section{Pennsylvania's Ethanol Corridor Project Surpasses 1 Million Gallons}

Greater Philadelphia Clean Cities (GPCC) reached a major milestone in alternative fuel deployment: In 2010, the coalition's ethanol project dispensed its millionth gallon of E85.

In 2006, GPCC set out to create an E85 corridor running from State College to Philadelphia. The project gained speed in the last year-and-a-half, with the number of public E85 stations along the route expanding from eight to 19 .

Funding for the project came from a state Alternative Fuels Incentive Grant (AFIG) and a project award from the U.S. Department of Energy. GPCC and its stakeholders used these funds to support the installation of E85 dispensers at gasoline stations and to educate the public. Outreach efforts included teaching consumers how use a vehicle identification number to determine E85 compatibility. GPCC engaged both large multistation retail fuel companies, such as AMERIgreen, Shipley Energy, and Sheetz, and small businesses like Dileo's Auto Service just outside of Philadelphia.

"What a fantastic day for Pennsylvania," says AMERIgreen's Seth Obetz "A few years ago, this fuel was only known in the Midwest. In the interest of our national security, we need every available domestically produced fuel to help lessen our dependence on imported foreign petroleum."

GPCC expects more stations will add their names to the list. When gas prices rise, so does the interest in ethanol, and the advent of the E85 corridor makes it a little easier for Pennsylvanians and people traveling through the state to use it.

\section{Ask the Technical Response Service}

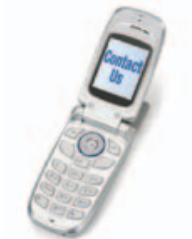

Do you have questions about alternative fuels, fuel economy measures, or advanced vehicles? The Clean Cities Technical Response Service (TRS) will help you find answers. For more information about the topics in this column or anything in the Clean Cities portfolio, e-mail technicalresponse@icfi.com, or call 800-254-6735.
Q: Will fuel economy labels look different with the introduction of new electric-drive vehicles?

A: In September 2010, U.S. Environmental Protection Agency (EPA) and the National Highway Traffic Safety Administration (NHSTA) released a proposed rule to change the fuel economy labels that appear on the windows of new vehicles being offered for sale. The goal of this label is to provide consumers with simple, straightforward comparisons across all vehicle types, including all-electric vehicles (EVs) and plug-in hybrid electric vehicles (PHEVs).

In addition to fuel economy, the proposed labels for all vehicles include estimated greenhouse gas emissions (in grams of $\mathrm{CO}_{2}$ per mile) and a fuel economy comparison with similar vehicle models. The proposed labels for EVs and PHEVs include driving range (miles between fueling/recharging), fuel economy in different operating modes (such as all-electric), and energy consumption (in miles per gallon equivalent).

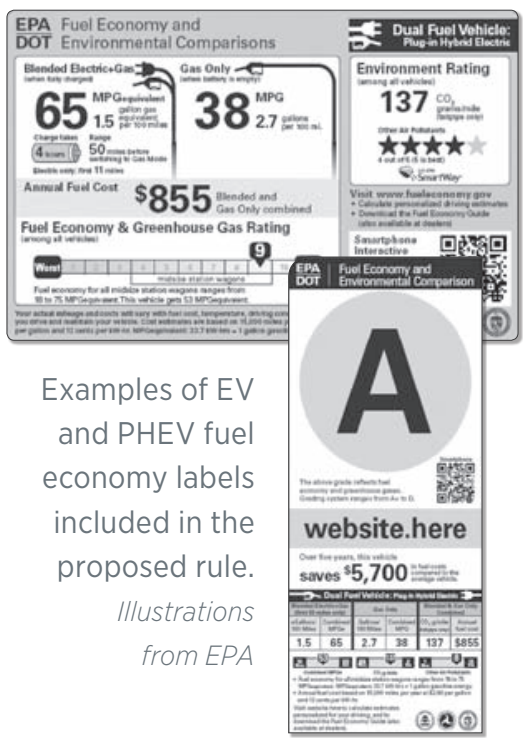

The proposed changes to fuel economy labels are set to take effect starting with model year 2012 vehicles. EPA is working with EV and PHEV manufacturers to develop labels under EPA's current regulations to use in the meantime. Refer to FuelEconomy.gov for fuel economy ratings and a link to the proposed rule.

Q: Now that EPA has granted a waiver for the use of E15 in newer vehicles, when will the fuel be available at the pump?

A: The waiver hinges on two conditions: (1) mitigating the potential for misfueling vehicles, engines, and equipment for which E15 is not approved and (2) ensuring fuel quality. EPA proposed a regulatory program to address potential misfueling concerns that would require E15 dispenser labeling, product transfer documents, and retail fueling stations surveys.

Ethanol and the resulting E15 must also meet fuel quality standards specified within state regulations. Additionally, updates and revisions to existing regulations and laws are necessary, including underground storage tank compatibility requirements and state laws that currently limit the sale of E15. Considering these complexities, the exact timeline for E15's entry into the marketplace is unclear and is likely to vary among regions. For more information, see the Technology Bulletin at www.afdc.energy.gov/afdc/ technology_bulletin_1210.html.

For more information about alternative energy or energy efficiency, you can also contact the EERE Info Center at 1-877-337-3463 or www.eere.energy.gov/ informationcenter. 


\section{Resources}

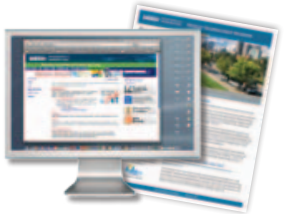

Clean Cities provides online tools and print resources for coordinators and stakeholders. Find all of these new documents and updated resources at www.afdc.energy.gov.

\section{Online Resources}

- National Parks Initiative Web Page: Visit the Clean Cities National Parks Initiative page (www.eere.energy.gov/cleancities/ national_parks.htm/) to find out how Clean Cities and the National Park Service are working together to improve air quality and reduce petroleum use in some of America's most special places.

\section{New Documents}

- Biodiesel Basics: This handy two-page fact sheet www.afdc. energy.gov/afdc/pdfs/47504.pdf provides quick answers to questions about biodiesel and points readers to sources of more in-depth information about using this alternative fuel.

\section{Clean Cities Light-Duty Vehicle Buyer's Guide: \\ The annual guide ( $w W w$.afdc.energy.gov/afdc) pdfs/49488. pdf) includes vehicle-specific information about fuel economy, emissions, vehicle specifications, and cost for the dozens of alternative fuel and advanced vehicles on the market this year.}

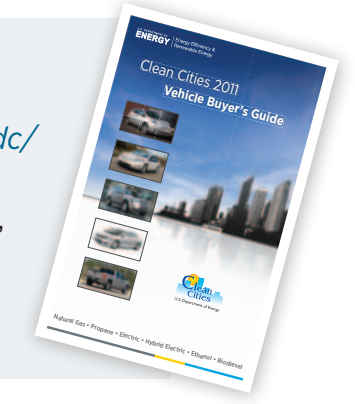

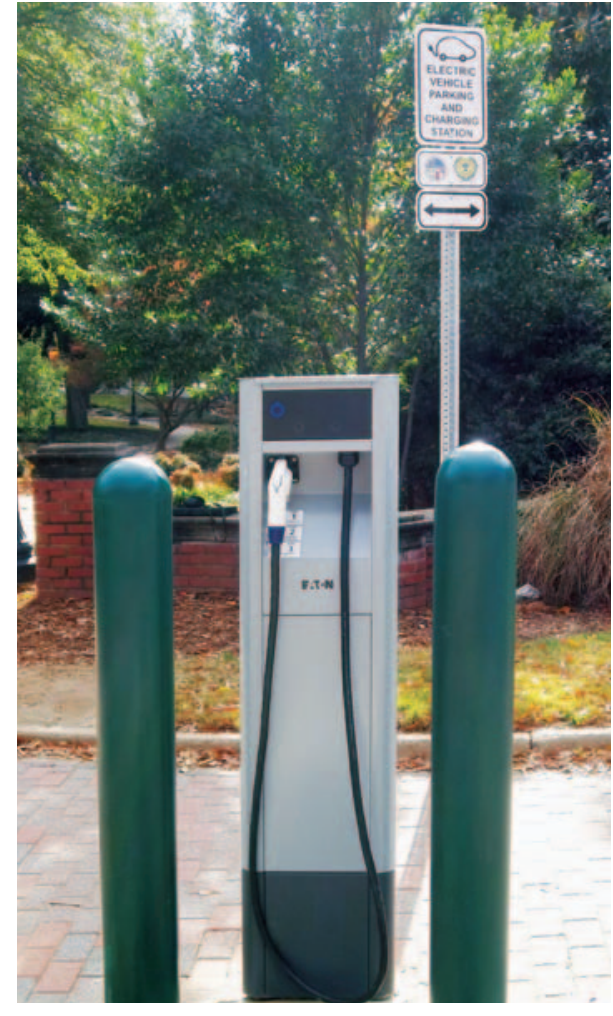

The City of Raleigh is installing PEV charging stations for free public use.

Photo from Kathy Boyer, Triangle Clean Cities Coalition/PIX 18520
> "Plug-In" from p7

"It's important for a coalition to identify key players early on and get them involved," says Coordinator Kathy Boyer. "Then you need to stay current with PEV issues in your area, like permitting and installation procedures, so you can get the right information to the people who need it - the PEV landscape changes quickly."
Raleigh is anticipating the arrival of PEVs in 2011. The City will operate up to 25 free public charging stations by mid 2011 (purchased with ARRA support). Other stakeholders are installing and collecting data from hundreds of additional stations throughout the Research Triangle Region. As a reflection of its efforts, Raleigh secured a highprofile PEV conference, set to take place in July 2011.

\section{National Plug-in Vehicle Programs}

\section{ChargePoint America, EV Project, Project Get Ready}

Oregon, Houston, Los Angeles, and Raleigh each participate in at least one of three prominent national PEV initiatives. Coulomb Technologies' ChargePoint America program (wWw.chargepointamerica.com) is deploying and collecting data from nearly 5,000 residential and public PEV charging stations in nine regions. ECOtality's EV Project (www.theevproject.com) is deploying and collecting data from about 15,000 residential and public PEV charging stations in 16 major cities. The goals of these projects, which are supported by ARRA through DOE, are to analyze the first wave of PEVs and stations and facilitate the transition to nationwide deployment. The Rocky Mountain Institute's Project Get Ready (www.projectgetready.org) is connecting the PEV-readiness efforts of its partner cities. Specific activities include creating a "menu" of PEV-readiness actions, helping cities create PEV coalitions, sharing lessons learned and best practices, documenting progress in PEV readiness, and providing educational materials.

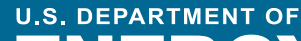
ENAROY

Energy Efficiency \& Renewable Energy
EERE Information Center 1-877-EERE-INFO (1-877-337-3463) www.eere.energy.gov/informationcenter

Printed with a renewable-source ink on paper containing at least $50 \%$ wastepaper, including $10 \%$ post consumer waste.
Prepared by the National Renewable Energy Laboratory (NREL), a national laboratory of the U.S. Department of Energy, Office of Energy Efficiency and Renewable Energy; NREL is operated by the Alliance for Sustainable Energy, LLC.

DOE/GO-102011-3202 • April 2011 